\title{
Kajian Analisis Perbandingan Rangka Atap Kuda- Kuda Menggunakan Kayu LVL dan Baja Ringan
}

\author{
NESSA VALIANTINE DIREDJA, BADRIANA NURANITA, \\ ERMA DESIMALIANA, ANISSA CAHYANI PERTIWI
}

\author{
Program Studi Teknik Sipil, Institut Teknologi Nasional Bandung, Indonesia \\ Email: nuranitabadriana@itenas.ac.id
}

\begin{abstract}
ABSTRAK
Penggunaan baja ringan sebagai material rangka atap sudah sangat umum ditemui. Selain baja ringan, terdapat alternatif material lain yaitu kayu LVL atau Laminated Veneer Lumber. Pada penelitian ini dibahas mengenai penggunaan material baja ringan dan LVL sebagai rangka atap kuda-kuda pada hunian. Berdasarkan perhitungan, luas penampang $A_{g}$ perlu antara kayu LVL terhadap baja ringan pada batang bawah memiliki perbandingan 7,31 dan 55,64, batang vertikal 6,10 dan 124,30, batang diagonal atas 33,67 dan untuk batang diagonal bawah 90,46 dan 5,33. Perbandingan tersebut menghasilkan $A_{g}$ perlu yang lebih besar untuk kayu LVL. Meskipun didapatkan $A_{g}$ perlu yang lebih kecil pada material baja ringan, namun terdapat persyaratan kelangsingan yang menyebabkan baja ringan memerlukan profil yang lebih besar. Sedangkan untuk lendutan didapatkan lendutan sebesar 0,88 mm rangka baja ringan dan 2,69 mm untuk kayu LVL, keduanya memenuhi persyaratan terhadap lendutan ijinnya. Untuk perbandingan berat, rangka baja ringan memiliki berat $24,99 \mathrm{~kg}$ dan kayu $L V L$ sebesar 7,71 kg.
\end{abstract}

Kata kunci: rangka atap kuda-kuda, baja ringan, kayu Laminated Veneer Lumber

\begin{abstract}
The use of cold-formed steel as a roof truss material is very common. In addition to cold-formed steel, there is other material alternatives that has a fairly light weight namely LVL or Laminated Veener Lumber. This study disscussed the used of cold-formed steel and LVL as a roof truss. The analysis result indicated that the section area $A_{\text {g required }}$ between $L V L$ to cold-form steel for bottom chord in the range of 7,31-55,64, and 6,10-124,30 for vertical beam, 33,67 for diagonal bottom chord, and 90,46-5,33 for diagonal top chord. As a result, Agreuired of $L V L$ was larger than cold-form steel. However, there are slendersness requirements that the cold-form steel was needed the larger profil than LVL. In terms of structure stiffness, the cold-form steel roof truss have 0,88 $\mathrm{mm}$ deflection and 2,69 $\mathrm{mm}$ for $L V L$, however they were able to accomodate the deflection requirements. The total weight of cold-formed steel is $24,99 \mathrm{~kg}$ and $7,71 \mathrm{~kg}$ for $\mathrm{LVL}$.
\end{abstract}

Keywords: roof truss, cold-formed steel, Laminated Veneer Lumber 
Nessa Valiantine Diredja, Badriana Nuranita, Erma Desimaliana, Anissa Cahyani Pertiwi

\section{PENDAHULUAN}

Seiring meningkatnya kebutuhan hunian di Indonesia, banyak pengembang mulai membangun hunian yang sesuai dengan kebutuhan serta keinginan masyarakat. Untuk mengurangi durasi pembangunan, material baja ringan banyak dilirik sebagai material yang tahan lama, anti rayap, kokoh, hemat biaya perawatan serta mudah dalam pemasangan. Pengunaan baja ringan dalam beberapa tahun terakhir, populer digunakan sebagai rangka atap bangunan. Selain memiliki kelebihan yang disebutkan sebelumnya, baja ringan juga memiliki kelemahan yaitu mudah mengalami tekuk dan mampu menghantarkan aliran listrik sehingga jika menggunakan baja ringan sebagai salah satu material rumah, instalasi listrik sangat perlu diperhatikan agar tidak membahayakan penghuni.

Selain baja ringan, bangunan rumah tinggal dengan menggunakan material kayu merupakan hal yang umum di Indonesia. Namun, material ini memiliki beberapa keterbatasan seperti dimensinya yang terbatas dan jika tidak dirawat dengan baik, maka material ini akan mudah mengalami kerusakan [5]. Maka, dewasa ini, para produsen semakin gencar melakukan berbagai inovasi, salah satunya adalah dengan teknologi kayu rekayasa Laminated Veneer Lumber (LVL), dimana kayu-kayu dibuat dalam lapisan tipis dan disatukan oleh bahan perekat sehingga terbentuk satu kesatuan material kayu yang solid.

Berdasarkan pertimbangan di atas, penelitian ini dilakukan untuk mengetahui kinerja kekuatan struktur rangka kuda-kuda melalui perbandingan dua material yang berbeda, yakni baja ringan dan LVL.

\section{TINJAUAN PUSTAKA}

\subsection{Konstruksi Rangka Atap}

Rangka atap merupakan konstruksi bagian paling atas pada rumah/gedung/bangunan yang bertujuan untuk memberikan perlindungan bagian bawah bangunan dari hujan, angin, panas, dan cuaca lainnya.

Fungsi rangka atap yang lebih spesifik adalah menerima beban oleh bobot sendiri, yaitu beban kuda-kuda dan bahan pelapis berarah vertikal kemudian meneruskannya pada kolom dan pondasi, serta dapat berfungsi untuk menahan tekanan angin muatan yang berarah horizontal pada gevel [8].

\subsection{Konstruksi Kuda-kuda}

Kuda-kuda merupakan salah-satu bagian struktur utama dari sebuah konstruksi rangka atap yang menyalurkan beban-beban dari struktur atas ke kolom dan balok suatu bangunan. Panjang bentang kuda-kuda pada kenyataannya berbeda-beda tergantung fungsi, lebar, dan bentang bangunan [7]. Pada kuda-kuda kayu, bentang optimum yang umumnya digunakan adalah hingga 12 meter, sedangkan kuda-kuda baja dapat mengakomodir beban rangka atap hingga bentang 75 meter.

\subsection{Baja Ringan}

Baja cold-formed atau cold rolled (canai dingin) atau dikenal umum sebagai baja ringan merupakan material baja yang berupa lembaran, pelat baja ataupun dengan proses pengerjaan baja dingin dan digunakan untuk konstrusi bangunan, material ini memiliki berbagai macam profil yang tersedia di pasaran, dengan kekuatan tarik relatif tinggi mencapai $550 \mathrm{Mpa}$. Analisis kekuatan struktur pada baja ringan baik gaya tekan maupun tarik, dapat dihitung menggunakan persamaan berikut ini [3]. 
Pada batang tarik, berlaku Persamaan 1 dan Persamaan 2 yaitu:

$$
\begin{gathered}
N^{*} \leq \phi_{t} N_{t} \\
N_{t}=0,85 K_{t} A_{n} F_{u}
\end{gathered}
$$

keterangan:

$N^{*}=$ gaya aksial desain $[\mathrm{N}]$,

$N_{t}=$ kapasitas penampang nominal dan komponen tarik struktur [N],

$\phi_{t}=$ faktor reduksi untuk tarik

$K_{t}=$ faktor koreksi

$A_{n}=$ luas netto penampang $\left[\mathrm{mm}^{2}\right]$,

$F_{u}=$ kekuatan tarik desain [MPa].

Sedangkan pada batang tekan, berlaku Persamaan 3 dan Persamaan 4 berikut.

$$
\begin{gathered}
N^{*} \leq \phi_{c} N_{c} \\
N_{c}=A_{e} f_{n}
\end{gathered}
$$

keterangan:

$N_{c}=$ kapasitas nominal tekan struktur [N],

$\phi_{c}=$ faktor reduksi untuk tekan

$A_{e}=$ luas efektif tegangan leleh $\left(f_{y}\right)\left[\mathrm{mm}^{2}\right]$,

$f_{n}=$ tegangan kritis $[\mathrm{MPa}]$.

\subsection{Kayu Laminated Veneer Lumber (LVL)}

Laminated Veneer Lumber (LVL) merupakan kayu olahan, dimana kayu dibuat dalam lapisanlapisan tipis yang disatukan oleh bahan perekat sehingga menjadi satu. LVL dikembangkan dengan menggunakan veneers dari jenis kayu yang ringan mudah cepat tumbuh seperti kayu sengon, yang mudah dikembangkan dan mempunyai waktu tumbuh yang cepat.

\subsubsection{Dasar Perancangan}

[2] mensyaratkan analisis gaya tekan dan gaya tarik sesuai penampang dapat mengikuti persamaan berikut.

Pada batang tarik, berlaku Persamaan 5 dan Persamaan 6.

$$
\begin{gathered}
T_{u} \leq T^{\prime} \\
T^{\prime}=F_{t}{ }^{\prime} \times A_{n}
\end{gathered}
$$

keterangan:

$T_{u}=$ gaya tarik terfaktor [N],

$T^{\prime}=$ tahanan tarik terkoreksi [N],

$F_{t}{ }^{\prime}=$ kuat tarik sejajar serat terkoreksi [MPa],

$A_{n}=$ luas penampang neto $\left[\mathrm{mm}^{2}\right]$.

Sedangkan pada batang tekan, berlaku Persamaan 7 dan Persamaan 8.

$$
\begin{gathered}
P_{u} \leq P^{\prime} \\
P^{\prime}=F_{c}{ }^{\prime} \times A_{g}
\end{gathered}
$$


keterangan:

$P_{u}=$ gaya tekan terfaktor $[\mathrm{N}]$,

$P^{\prime}=$ kapasitas tekan terkoreksi [N],

$F_{c}{ }^{\prime}=$ kuat tekan sejajar serat terkoreksi [MPa],

$A_{g}=$ luas penampang bruto $\left[\mathrm{mm}^{2}\right]$.

\subsection{Pembebanan dan Kombinasi}

Beban-beban yang diaplikasikan pada penelitian ini adalah beban struktur, beban mati tambahan, beban hidup, dan beban angin, seperti penjelasan singkat di bawah ini:

1. Beban mati struktur, yakni beban sendiri struktur kuda-kuda.

2. Beban mati tambahan, yakni beban mati dari komponen struktur tambahan yang sifatnya permanen, seperti penutup atap, gording, plafon, dan penggantung.

3. Beban hidup, yakni berupa beban selama perawatan oleh pekerja ataupun selama penggunaan biasa dengan mengambil beban sebesar $100 \mathrm{~kg}$.

4. Beban angin, tekanan angin dipengaruhi oleh kemiringan atap dan lokasi bagunan, pada penelitian ini diambil tekanan sebesar $25 \mathrm{~kg} / \mathrm{m}^{2}$, yang dikalikan dengan koefisien angin tekan $C_{t}$ dan koefisien angin hisap $C_{h}$ (dengan $C_{t}=(0,02 \alpha-0,4), C_{h}=-0,4$, dan $\alpha=$ sudut kemiringan atap).

Adapun kombinasi pembebanan yang digunakan pada penelitian ini, terdiri dari: $1,4 \mathrm{DL} ; 1,2 \mathrm{DL}$ $+0,5 \mathrm{Lr} ; 1,2 \mathrm{DL}+1,6 \mathrm{Lr}+0,5 \mathrm{~W} ; 1,2 \mathrm{DL}+1,0 \mathrm{~W}+0,5 \mathrm{~L} ;$ dan 0,9DL + 1,0W.

\section{METODOLOGI PENELITIAN}

\subsection{Studi Pustaka}

Bertujuan untuk menjelaskan teori-teori secara ringkas mengenai konstruksi rangka atap, penggunaan kuda-kuda baja ringan dan $\mathrm{LVL}$, pembebanan dan analisis, yang bersumber dari berbagai literatur baik SNI, buku, maupun jurnal-jurnal ilmiah terdahulu.

\subsection{Penentuan Layout Rangka Atap}

Rangka atap kuda-kuda yang digunakan dalam penelitian ini adalah rangka atap dengan bentang 8 meter dan memiliki sudut $32^{\circ}$. Berikut merupakan data-data material yang digunakan dalam penelitian ini dapat dilihat pada Tabel 1. Tabel 2 merupakan tabel profil baja ringan tipe G550 sesuai [3].

Tabel 1. Data Material

\begin{tabular}{lcc}
\hline \multicolumn{1}{c}{ Data Material } & \multicolumn{2}{c}{ Material } \\
\cline { 2 - 3 } Mutu baja & Baja Ringan & LVL \\
\hline$F y[\mathrm{MPa}]$ & 550 & - \\
\hline $\mathrm{Fu}[\mathrm{MPa}]$ & 550 & - \\
\hline Berat jenis [Kg/m $\left.{ }^{3}\right]$ & 7.400 & 410 \\
\hline Modulus elastisitas [MPa] & 200.000 & 5700 \\
\hline Modulus geser [MPa] & 80.000 & - \\
\hline Poisson, U & 0,3 & 0,225 \\
\hline Kuat tekan sejajar serat acuan [MPa] & - & 23,12 \\
\hline Kuat tarik sejajar serat [MPa] & - & 48,58 \\
\hline (Sumber: SNI 8399:2017; Eratodi, B. \& Awaludin, A., \\
(2017); Setyowati, Basuki, A. \& Setiono, (2013))
\end{tabular}


Tabel 2. Profil Baja Ringan

\begin{tabular}{|c|c|c|c|c|c|c|c|c|}
\hline \multirow{4}{*}{ Profil } & \multirow{2}{*}{\multicolumn{2}{|c|}{ Dimension }} & \multirow{3}{*}{$\begin{array}{c}\begin{array}{c}\text { Section } \\
\text { Area }\end{array} \\
A\end{array}$} & \multirow{3}{*}{$\begin{array}{c}\text { Unit } \\
\text { Weight }\end{array}$} & \multicolumn{4}{|c|}{ Informative Reference } \\
\hline & & & & & \multicolumn{2}{|c|}{$\begin{array}{c}\text { Geometrical } \\
\text { Moment of Inertia }\end{array}$} & \multicolumn{2}{|c|}{$\begin{array}{c}\text { Modulus } \\
\text { of Section }\end{array}$} \\
\hline & $H \times B \times C$ & $t$ & & & $I_{x}$ & $I_{y}$ & $S_{x}$ & $S_{y}$ \\
\hline & {$[\mathrm{mm}]$} & {$[\mathrm{mm}]$} & {$\left[\mathrm{mm}^{2}\right]$} & {$[\mathrm{kg} / \mathbf{m}]$} & {$\left[\mathrm{mm}^{4}\right]$} & {$\left[\mathrm{mm}^{4}\right]$} & {$\left[\mathrm{mm}^{3}\right]$} & {$\left[\mathrm{mm}^{3}\right]$} \\
\hline $\mathrm{C} 75$ & $C 74 \times 24 \times 10$ & 0,8 & 108,29 & 0,861 & $87.796,10$ & $8.902,84$ & $2.372,87$ & 535,43 \\
\hline $\mathrm{C} 70$ & C68×19×8 & 0,8 & 92,29 & 0,766 & $60.815,88$ & $4.466,65$ & $1.788,70$ & 328,39 \\
\hline $\mathrm{C} 60$ & $\mathrm{C} 60 \times 34 \times 10$ & 0,5 & 71,93 & 0,483 & $43.580,17$ & $1.2346,60$ & $1.452,67$ & 570,08 \\
\hline
\end{tabular}

(Sumber: SNI 8399:2017)

\subsection{Pemodelan Struktur}

Pendefinisian model, pembebanan dan analisis struktur menggunakan software SAP2000. Berikut pada Gambar 1 merupakan model struktur kuda-kuda yang dianalisis.

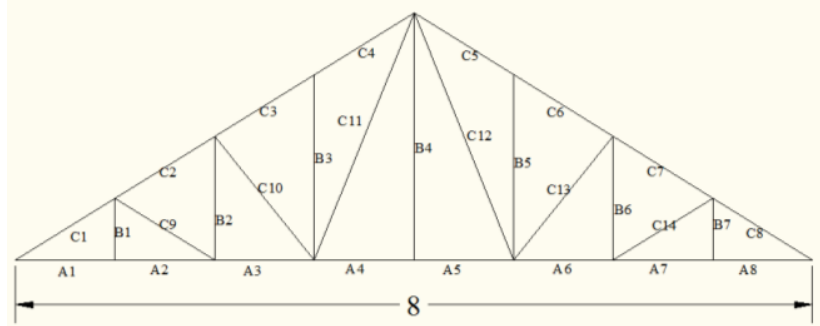

Gambar 1. Model struktur kuda-kuda dengan keterangan nama batang

\subsection{Analisis Struktur Rangka Atap}

Perhitungan struktur dilakukan dua kali, yakni terhadap rangka atap menggunakan material baja ringan, kedua terhadap rangka atap dengan material kayu LVL. Perhitungan struktur untuk kedua material tersebut relatif sama menggunakan software SAP2000, dimana yang pertama dilakukan adalah membuat permodelan dengan lebar bentang dan mutu material yang sudah ditentukan, kemudian memasukan beban-beban terkait. Setelah dilakukan analisis struktur menggunakan software SAP2000, selanjutnya menganalisis output gaya tekan, gaya tarik untuk mendapatkan profil penampang yang kuat dan ekonomis.

\section{ANALISIS DAN PEMBAHASAN}

Penempatan untuk beban-beban yang diaplikasikan pada kuda-kuda dapat dilihat pada Gambar 2, Gambar 3, dan Gambar 4 berikut.

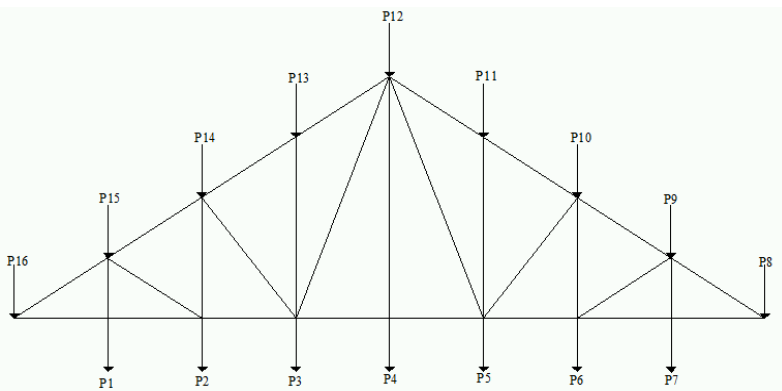

Gambar 2. Aplikasi beban mati tambahan

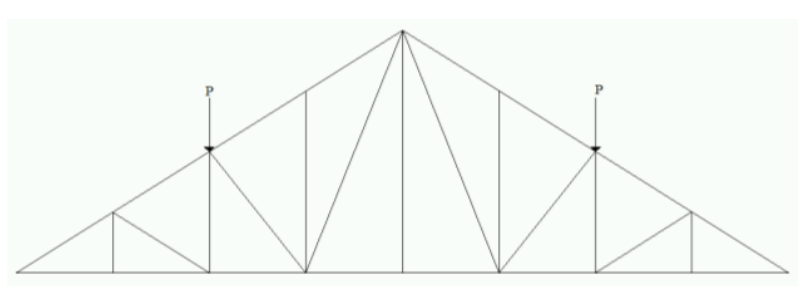

Gambar 3. Aplikasi beban hidup 


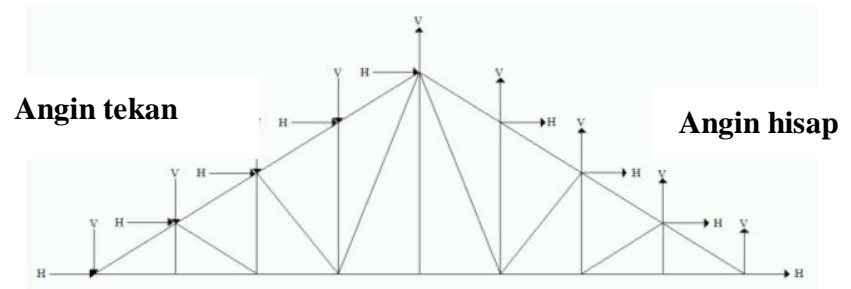

Gambar 4. Aplikasi beban angin

Selanjutnya hasil analisis struktur pada masing-masing batang, diperlihatkan pada Tabel 3.

Tabel 3. Rekapitulasi Gaya Batang Maksimum (Outkput SAP2000)

\begin{tabular}{cccc}
\hline Batang & Kombinasi & Gaya Tekan [N] & Gaya Tarik [N] \\
\hline Batang bawah A1 & Comb 3 & - & $1.318,6$ \\
\hline Batang bawah A4 & Comb 3 & $2.165,77$ & - \\
\hline Batang Vertikal B2 & Comb 3 & - & $1.099,87$ \\
\hline Batang Vertikal B3 & Comb 3 & 293,33 & - \\
\hline Batang diagonal atas C1 & Comb 3 & $8.239,96$ & - \\
\hline Batang diagonal bawah C12 & Comb 3 & - & $3.127,32$ \\
\hline Batang diagonal bawah C13 & Comb 3 & $2.529,03$ & - \\
\hline
\end{tabular}

Berdasarkan nilai gaya batang maksimum yang terdapat pada Tabel $\mathbf{3}$, selanjutnya dihitung luas profil penampang yang dibutuhkan $\left(A_{\text {g perlu }}\right)$ oleh baja ringan dan LVL beserta perbandingannya seperti pada Tabel 4. Berdasarkan Tabel 4, dihasilkan nilai $A_{g}$ perlu baja ringan lebih kecil dibandingkan dengan kayu LVL, sehingga dapat dikatakan bahwa kekuatan baja ringan lebih besar dibandingkan dengan kayu LVL.

Tabel 4. Perbandingan $\boldsymbol{A}_{g}$ perlu LVL terhadap Baja Ringan

\begin{tabular}{|c|c|c|c|c|}
\hline No. Batang & $\begin{array}{l}\text { Posisi } \\
\text { Batang }\end{array}$ & Material & $\begin{array}{l}A_{g} \text { perlu } \\
{\left[\mathrm{mm}^{2}\right]}\end{array}$ & $\begin{array}{c}\text { Perbandingan } \\
\text { LVL terhadap } \\
\text { Baja Ringan }\end{array}$ \\
\hline$A 1, A 2, A 3, A 6, A 7$, & \multirow{4}{*}{ Bawah } & Baja Ringan & 2,69 & \multirow{2}{*}{7,31} \\
\hline $\mathrm{A} 8$ & & LVL & 19,63 & \\
\hline \multirow{2}{*}{ A4, A5 } & & Baja Ringan & 6,95 & \multirow{2}{*}{55,64} \\
\hline & & LVL & 386,63 & \\
\hline \multirow{2}{*}{$\begin{array}{c}\text { B1, B2, B4, B5, B6, } \\
\text { B7 }\end{array}$} & \multirow{4}{*}{ Vertikal } & Baja Ringan & 2,69 & \multirow{2}{*}{6,10} \\
\hline & & LVL & 16,38 & \\
\hline \multirow{2}{*}{ B3 } & & Baja Ringan & 0,94 & \multirow{2}{*}{124,30} \\
\hline & & LVL & 116,97 & \\
\hline \multirow{2}{*}{$\begin{array}{c}\mathrm{C} 1, \mathrm{C} 2, \mathrm{C} 3, \mathrm{C} 4, \mathrm{C} 5, \\
\mathrm{C} 6, \mathrm{C} 7, \mathrm{C} 8\end{array}$} & \multirow{2}{*}{$\begin{array}{l}\text { Diagonal } \\
\text { atas }\end{array}$} & Baja Ringan & 26,44 & \multirow{2}{*}{33,67} \\
\hline & & LVL & 890,23 & \\
\hline \multirow{2}{*}{$\mathrm{C} 9, \mathrm{C} 10, \mathrm{C} 13, \mathrm{C} 14$} & \multirow{4}{*}{$\begin{array}{l}\text { Diagonal } \\
\text { bawah }\end{array}$} & Baja Ringan & 8,11 & \multirow{2}{*}{90,46} \\
\hline & & LVL & 733,99 & \\
\hline \multirow{2}{*}{$\mathrm{C} 11, \mathrm{C} 12$} & & Baja Ringan & 8,74 & \multirow{2}{*}{5,33} \\
\hline & & LVL & 46,57 & \\
\hline
\end{tabular}

Namun demikian, meskipun pada baja ringan hanya dibutuhkan Ag perlu lebih kecil dari LVL, nyatanya terdapat parameter lain yang membuat pada penelitian ini, digunakan profil baja ringan yang justru malah menghasilkan Ag lebih besar dari yang diperlukan. Hal tersebut berkaitan dengan faktor kelangsingan yang membuat pada baja ringan memiliki profil minimum. Akibatnya, baja ringan pada penelitian ini memerlukan penggunaan luas penampang $\left(A_{\text {g pakai }}\right)$ yang besar, sehingga profilnya pun relatif besar. Adapun perbandingan profil baja ringan dan LVL disajikan pada Tabel 5. 
Tabel 5. Persentase Perbandingan $A_{\text {g profil pakai }}$ antara LVL terhadap Baja Ringan

\begin{tabular}{|c|c|c|c|c|c|}
\hline No. Batang & $\begin{array}{l}\text { Posisi } \\
\text { Batang }\end{array}$ & Material & Profil & $\begin{array}{c}A_{g} \\
{\left[\mathbf{m m}^{2}\right]}\end{array}$ & $\begin{array}{c}\text { Perbandingan } \\
\text { LVL terhadap } \\
\text { Baja Ringan }\end{array}$ \\
\hline$A 1, A 2, A 3, A 6, A 7$, & \multirow{4}{*}{ Bawah } & Baja Ringan & $\mathrm{C} 60 \times 34 \times 10$ & 71,93 & \multirow{2}{*}{2,78} \\
\hline $\mathrm{A} 8$ & & LVL & $10 \times 20$ & 200 & \\
\hline \multirow{2}{*}{ A4, A5 } & & Baja Ringan & C68x19x8 & 92,29 & \multirow{2}{*}{5,22} \\
\hline & & LVL & $15 \times 32$ & 480 & \\
\hline \multirow{2}{*}{$\begin{array}{c}\mathrm{B} 1, \mathrm{~B} 2, \mathrm{~B} 4, \mathrm{~B} 5, \mathrm{~B} 6, \\
\text { B7 }\end{array}$} & \multirow{4}{*}{ Vertikal } & Baja Ringan & $\mathrm{C} 60 \times 34 \times 10$ & 71,93 & \multirow{2}{*}{2,36} \\
\hline & & LVL & $10 \times 17$ & 170 & \\
\hline \multirow{2}{*}{ B3 } & & Baja Ringan & $C 74 \times 25 \times 10$ & 116,41 & \multirow{2}{*}{4,12} \\
\hline & & LVL & $12 \times 40$ & 480 & \\
\hline \multirow{2}{*}{$\begin{array}{c}\mathrm{C} 1, \mathrm{C} 2, \mathrm{C} 3, \mathrm{C} 4, \mathrm{C} 5, \\
\mathrm{C} 6, \mathrm{C} 7, \mathrm{C} 8\end{array}$} & \multirow{2}{*}{$\begin{array}{c}\text { Diagonal } \\
\text { atas }\end{array}$} & Baja Ringan & $C 74 \times 24 \times 10$ & 108,29 & \multirow{2}{*}{8,59} \\
\hline & & LVL & $19 \times 49$ & 931 & \\
\hline \multirow{2}{*}{$\mathrm{C} 9, \mathrm{C} 10, \mathrm{C} 13, \mathrm{C} 14$} & \multirow{4}{*}{$\begin{array}{c}\text { Diagonal } \\
\text { bawah }\end{array}$} & Baja Ringan & C74×24x8 & 98,84 & \multirow{2}{*}{7,69} \\
\hline & & LVL & $19 \times 40$ & 760 & \\
\hline \multirow{2}{*}{$\mathrm{C} 11, \mathrm{C} 12$} & & Baja Ringan & $\mathrm{C} 60 \times 34 \times 10$ & 71,93 & \multirow{2}{*}{3,50} \\
\hline & & LVL & $12 \times 21$ & 252 & \\
\hline
\end{tabular}

Berdasarkan dimensi profil yang diperoleh pada Tabel 6, didapatkan nilai kapasitas masingmasing batang, baik gaya tarik maupun tekan yang dapat dilihat pada Tabel 7.

Tabel 6. Rekapitulasi Profil Penampang Kuda-kuda

\begin{tabular}{cccc}
\hline \multirow{2}{*}{ Nama Batang } & Posisi batang & \multicolumn{2}{c}{$\begin{array}{c}\text { Profil Penampang } \\
\text { [mm] }\end{array}$} \\
\cline { 3 - 4 } & & Baja Ringan & LVL \\
\hline $\mathrm{A} 1, \mathrm{~A} 2, \mathrm{~A} 3, \mathrm{~A} 6, \mathrm{~A} 7, \mathrm{~A} 8$ & Bawah & $\mathrm{C} 60 \times 34 \times 10$ & $10 \times 20$ \\
\hline $\mathrm{A} 4, \mathrm{~A} 5$ & Bawah & $\mathrm{C} 68 \times 19 \times 8$ & $15 \times 32$ \\
\hline $\mathrm{B} 1, \mathrm{~B} 2, \mathrm{~B} 4, \mathrm{~B} 5, \mathrm{~B} 6, \mathrm{~B} 7$ & Tegak & $\mathrm{C} 60 \times 34 \times 10$ & $10 \times 17$ \\
\hline $\mathrm{B} 3$ & Tegak & $\mathrm{C} 74 \times 25 \times 10$ & $12 \times 40$ \\
\hline $\mathrm{C} 1, \mathrm{C} 2, \mathrm{C} 3, \mathrm{C} 4, \mathrm{C} 5, \mathrm{C} 6, \mathrm{C} 7$, & Diagonal atas & $\mathrm{C} 74 \times 24 \times 10$ & $19 \times 49$ \\
$\mathrm{C} 8$ & Diagonal bawah & $\mathrm{C} 74 \times 24 \times 8$ & $19 \times 40$ \\
\hline $\mathrm{C} 9, \mathrm{C} 10, \mathrm{C} 13, \mathrm{C} 14$ & Diagonal bawah & $\mathrm{C} 60 \times 34 \times 10$ & $12 \times 21$ \\
\hline $\mathrm{C} 11, \mathrm{C} 12$ & &
\end{tabular}

Tabel 7. Persentase Perbandingan Kapasitas Baja Ringan terhadap LVL

\begin{tabular}{|c|c|c|c|c|c|}
\hline $\begin{array}{c}\text { Tipe } \\
\text { Batang }\end{array}$ & Material & $\begin{array}{c}\text { Kapasitas } \\
\text { [N] }\end{array}$ & $\begin{array}{c}\text { Persentase } \\
\text { Perbandingan } \\
\text { Kapasitas LVL } \\
\text { terhadap Baja } \\
\text { Ringan } \\
\text { [\%] } \\
\end{array}$ & $\begin{array}{c}\text { Kapasitas } \\
\text { [N] }\end{array}$ & $\begin{array}{c}\text { Perbandingan } \\
\text { Kapasitas LVL } \\
\text { terhadap Baja } \\
\text { Ringan } \\
\text { [\%] }\end{array}$ \\
\hline \multirow{2}{*}{ Bawah } & Baja ringan & $8.295,79$ & \multirow{2}{*}{67,59} & $21.865,22$ & \multirow{2}{*}{50,86} \\
\hline & LVL & $2.688,77$ & & $10.745,12$ & \\
\hline \multirow{2}{*}{ Vertikal } & Baja ringan & $6.434,28$ & \multirow{2}{*}{81,29} & $21.865,22$ & \multirow{2}{*}{58,23} \\
\hline & LVL & $1.203,66$ & & $9.133,25$ & \\
\hline \multirow{2}{*}{$\begin{array}{l}\text { Diagonal } \\
\text { atas }\end{array}$} & Baja ringan & $14.923,95$ & \multirow{2}{*}{42,26} & - & \multirow{2}{*}{-} \\
\hline & LVL & $8.617,36$ & & - & \\
\hline \multirow{2}{*}{$\begin{array}{l}\text { Diagonal } \\
\text { bawah }\end{array}$} & Baja ringan & $5.895,82$ & \multirow{2}{*}{55,58} & $21.865,22$ & \multirow{2}{*}{38,08} \\
\hline & LVL & $2.618,65$ & & $13.538,85$ & \\
\hline
\end{tabular}

Adapun persentase perbandingan antara berat total struktur antara baja ringan dan LVL, dapat dilihat pada Tabel 8 berikut ini. 
Tabel 8. Berat Total Struktur (Uutput SAP2000)

\begin{tabular}{ccc} 
Rangka Atap & $\begin{array}{c}\text { Berat Struktur } \\
{[\mathbf{k g}]}\end{array}$ & $\begin{array}{c}\text { Persentase } \\
\text { Perbandingan LVL } \\
\text { terhadap Baja Ringan } \\
{[\%]}\end{array}$ \\
\hline Baja ringan & 24,99 & 69,148 \\
\hline LVL & 7,71 & 6
\end{tabular}

Selanjutnya, dihitung pula nilai lendutan yang dihasilkan oleh masing-masing rangka kudakuda, baik baja ringan maupun LVL. Berdasarkan hasil perbandingan yang terdapat pada Tabel 9, baja ringan memiliki nilai lendutan lebih kecil dibandingkan dengan kayu LVL.

Tabel 9. Perbandingan Lendutan dengan Lendutan Izin

\begin{tabular}{|c|c|c|c|}
\hline Rangka Atap & $\begin{array}{c}\text { Nilai Lendutan } \\
{[\mathrm{mm}]}\end{array}$ & $\begin{array}{c}\text { Lendutan Izin } \\
{[\mathrm{mm}]}\end{array}$ & Keterangan \\
\hline Baja Ringan & 0,88 & $L-8000$ & ok \\
\hline LVL & 2,69 & $\begin{array}{rl}240 & 240 \\
= & 33,333\end{array}$ & ok \\
\hline
\end{tabular}

\section{KESIMPULAN}

Kesimpulan yang diperoleh dari penelitian ini adalah sebagai berikut:

1. Perancangan batang tarik dan tekan pada kayu LVL dan baja ringan menghasilkan dimensi

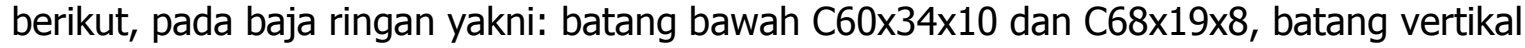

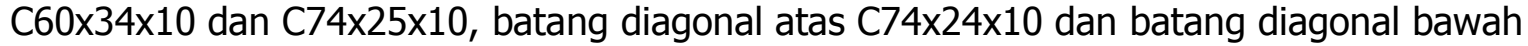

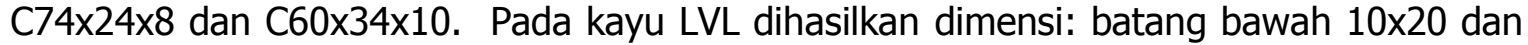
$15 \times 32$, batang vertikal $10 \times 17$ dan $12 \times 40$, batang diagonal atas $19 \times 49$, dan pada batang diagonal bawah $19 \times 40$ dan $12 \times 21$.

2. Perbandingan luas penampang perlu $\left(A_{g \text { perlu }}\right)$ antara baja ringan dan kayu LVL menghasilkan perbandingan 7,31 dan 55,64 untuk batang bawah; untuk batang vertikal sebesar 6,10 dan 124,30; batang diagonal atas sebesar 33,67; dan batang diagonal bawah sebesar 90,46 dan 5,33; halmana kayu LVL lebih besar daripada baja ringan. Hal ini dikarenakan kekuatan baja ringan lebih besar dibandingkan dengan kayu LVL.

3. Meskipun $A_{\text {g perlu }}$ untuk baja ringan lebih kecil dibandingkan kayu LVL, terdapat persyaratan kelangsingan sehingga baja ringan memiliki dimensi minimum yang dapat digunakan.

4. Hasil analisis kapasitas menghasilkan perbandingan baja ringan terhadap kayu LVL, yaitu: pada batang bawah baja ringan, kapasitas tekan 67,59\% lebih besar dibandingkan dengan kayu LVL; dan untuk batang tarik 50,86\% lebih besar dibandingkan kayu LVL. Pada batang vertikal, kapasitas tekan baja ringan lebih besar $81,29 \%$ dibandingkan kayu LVL; dan batang tarik $58,23 \%$ lebih besar dibandingkan kayu LVL. Pada batang diagonal atas, kapasitas tekan baja ringan 42,26\% lebih besar dibandingkan dengan kayu LVL. Pada batang diagonal bawah, kapasitas tekan baja ringan 55,58\% lebih besar dibandingkan dengan kayu LVL; dan batang tarik 38,08\% lebih besar dibandingkan dengan kayu LVL.

5. Hasil analisis kekakuan menghasilkan lendutan pada baja ringan sebesar $0,88 \mathrm{~mm}$ dan pada kayu LVL sebesar 2,69 mm; keduanya memenuhi persyaratan kekakuan karena lendutan yang terjadi kurang dari lendutan izin sebesar 33,33 mm.

6. Material baja ringan lebih berat dibandingkan kayu $L V L$, dengan rasio perbedaan sebesar $69,148 \%$. Berat baja ringan sebesar 24,99 kg sedangkan berat kayu LVL sebesar 7,71 kg. Perbedaan ini dipengaruhi oleh penggunaan kayu LVL yang dapat disesuaikan dimensinya, sedangkan penggunaan profil baja ringan terbatas pengunaannya sesuai dengan dimensi 
yang tersedia di pasaran. Namun demikian, hal ini dapat diatasi dengan pemilihan bentuk rangka kuda-kuda lain sehingga baja ringan tidak terkena batas kelangsingan terlalu tinggi dan diharapkan dapat menggunakan profil yang lebih ekonomis.

\section{DAFTAR PUSTAKA}

[1] Badan Standardisasi Nasional. (2013). SNI 7971-2013 tentang Struktur Baja Canai Dingin. Jakarta: Badan Standardisasi Nasional.

[2] Badan Standardisasi Nasional. (2013). SNI 7973-2013 tentang Spesifikasi Desain untuk Konstruksi Kayu. Jakarta: Badan Standardisasi Nasional.

[3] Badan Standardisasi Nasional. (2017). SNI 8399-2017 tentang Profil Rangka Atap Baja Ringan. Jakarta: Badan Standardisasi Nasional.

[4] Basuki, A. (2016). Laminated Veneer Lumber (LVL) Kayu Sengon Sebagai Aalternatif Kayu Konstruksi.

[5] Diredja, N.V., et al. (2019). Analisis Kinerja Struktur Bangunan Rumah Tinggal dengan Kayu Glulam Mahoni. Jurnal Rekayasa Hijau, 3 (3), 205-216.

[6] Eratodi, B. \& Awaludin, A. (2017). Bending Capacity of Non-prismatic LVL Beams Paraserianthes Falcataria. Procedia Engineering, 171, 1362-1369.

[7] Nuranita, B. \& Herbudiman, B. (2020). Analisis Perbandingan Metode DTI dan DFBK pada Rangka Atap Kayu untuk Bangunan Gudang Berdasarkan SNI 7973:2013. KonTekS-14 Konferensi Nasional Teknik Sipil 14, pp. 588-597. Bandung: Institut Teknologi Bandung.

[8] Pangaribuan, M. R. (2014). Baja Ringan sebagai Pengganti Kayu dalam Pembuatan Rangka Atap Bangunan Rumah Masyarakat. Jurnal Teknik Sipil dan Lingkungan, 2 (4), 648655.

[9] Setyowati, Basuki, A. \& Setiono. (2013). Algoritma Peracangan Struktur Rangka Atap Kudakuda Laminated Veneer Lumber (LVL) Kayu Sengon. Matriks Teknik Sipil, 1 (4), 556572. 